\title{
Knowledge, attitude, and practice towards COVID-19 among Libyan people- a web-based cross-sectional study
}

\author{
Saad Ahmed Ali Jadoo ${ }^{1 *}$, Omar Mohamed Danfour ${ }^{2}$, Masud Zerzah ${ }^{3}$, Mouna Abdelrahman \\ Abujazia ${ }^{4}$, Perihan Torun ${ }^{5}$, Mustafa Ali Mustafa Al-Samarrai ${ }^{6}$, Shukur Mahmood Yaseen ${ }^{7}$
}

\begin{abstract}
Background: Successful plans in disaster and epidemics management depend on the feedback response and the assessment of knowledge, attitudes, and practices among the target population. This study aims to assess the knowledge, attitude, and practice towards COVID-19 among Libyan people.

Methods: A cross-sectional web-based survey designed to assess the knowledge, attitude, and practice towards COVID-19 among the Libyan people from 13-20 October 2020. A self-administered questionnaire was recruited to collect the data of 287 participants. SPSS version 16.0 was used to analyze the data using univariate and multivariable regression data analyses.

Results: More than half of respondents were males (53.7\%), married (61.3\%), aged less than 45 years old, highly educated $(46.3 \%)$, employed $(44.6 \%)$, urban resident $(79.8 \%)$, experience good or very good health $(71.1 \%)$ and earned more than USD 200 monthly (84.3\%). The participants showed a high rate of good knowledge (81.0\%), attitude (71.1\%), and practice (83.7\%) towards COVID-19, respectively. Regression analysis showed that married $(P=0.056)$, female $(P=0.037)$, living in the urban regions $(P<0.001)$ with good income of more than USD $2020(P=0.001)$ were significantly associated with upper knowledge score. Females $(P=0.040)$ were more significantly associated with positive attitude scores than males. Regarding practice score, married $(P=0.001)$, females $(P=0.059)$ had better practice, but poor-rated health status $(P=0.018)$ was significantly associated with the weak practice.

Conclusion: The distinction of urban regions with good knowledge, optimistic attitudes, and acceptable practices towards COVID-19 determines the government's action compass towards more interest in supporting males, unhealthy, and those living in the rural areas with accurate and timely knowledge.
\end{abstract}

Keywords: COVID-19, Knowledge, Attitude, Practice, Public, Preventive Measures, Web-based, Libya

\section{Background}

Libya is an Arabic, North African oil country and among the upper-middle-income economies [1,2]. The desert lands that make up more than ninety percent of the country's area, the scarcity of fresh, natural water, and the absence of rivers pushed about $85.0 \%$ of the population to live in an area less than $10.0 \%$ near the sea's coast mainly in three historic known regions including "Tripolitania in the west, Cyrenaica in the east, and Fezzan in the south" [2,3]. The distinctive geographical location linking Europe and Africa, the long coast overlooking the Mediterranean Sea, and the rich natural resources made Libya a target for many greedy people [2,4]. Since 2001, Libya has been

*Correspondence: drsaadalezzi@gmail.com

${ }^{1}$ Department of Public Health, Faculty of Medicine, Bezmialem Vakif University, Istanbul, Turkey

A full list of author information is available at the end of the article in a state of security, political and economic instability. The internal conflicts resulted in the squandering of oil wealth, the destruction of the infrastructure, and the shortage of professional workforce, including human resources for health [2]. In early 2020, Libya topped the list of the world countries (after Afghanistan) as the second-highest country in the prevalence of violence against health care workers and health institutions [5].

Libyan health system

Both public and private sectors have engaged in providing healthcare services in Libya. Nevertheless, the Ministry of Health $(\mathrm{MoH})$ is directly responsible for all financing, resource allocation, planning, organizing, evaluation, and monitoring operations, in addition to inspecting and supervising national and international bodies, including general and specialized 
hospitals, research, and training institutions [6]. The Ministry of Health provides free-of-charge health services to citizens at primary, secondary, and tertiary levels. Primary health care services included 728 primary health care units, 571 primary health care centers, and 56 dispensaries scattered in Libyan cities, districts, and villages. However, half of them became out of service at the end of 2019. The secondary health services were distributed among 32 rural hospitals, 23 general hospitals, 31 teaching hospitals, and 11 specialized hospitals. At the tertiary level, Libyans receive advanced health services in five medical centers for tertiary care in addition to specialized and teaching hospitals [5].

\section{Current situation of COVID 19}

Although Libya was among the last countries to be invaded by the novel human coronavirus (SARS-COV-2), it was not prepared to face the crisis as is the case in most countries of the world [7]. The first case of COVID-19 disease was officially announced on the twenty-fourth of March 2020 [8]. The prevalence rate of COVID-19 infection has steadily increased since the beginning of August 2020. Up to $31^{\text {st }}$ March 2021, the total reported cases in Libya was 158,957 , with 2,667 deaths and 9,143 active cases [9]. In light of the worldwide worsening of the COVID-19 crisis and the upcoming new waves of the pandemic [10], the assessment of public knowledge, attitude, and practice toward the COVID-19 emerge as a vital issue when planning to face the crisis.

Since $11^{\text {th }}$ March 2020, when the World Health Organization (WHO) reported that COVID-19 is a global pandemic [11], several studies [12-25] have been conducted to test the knowledge, attitude, and practice (KAP) toward the COVID-19 pandemic among different societies. Most of the previous studies found good knowledge, various attitudes, and acceptable practice among the surveyed populations. At the local level, two independent studies conducted by Hweissa NAB, et al. [26] and Elshwekh H, et al. [27] found that $79.9 \%$ and $89.3 \%$ of the surveyed Libyan healthcare workers have adequate knowledge about the COVID-19, respectively. Elhadi M, et al. [28] surveyed 3,669 medical and non-medical students from fifteen universities in Libya. The authors found that $71.8 \%$ had adequate knowledge accompanied by a positive attitude and professional behavior towards COVID-19. The present study aimed to assess the KAP towards COVID-19 among the Libyan people.

\section{Methods}

Study Design and Sample

A cross-sectional study designed to assess the knowledge, attitude, and practice towards COVID-19 among the Libyan people. A web-based and self-administered questionnaire was recruited to collect the data from 13-20 October 2020. The Google Docs Forms were used to create a link to the survey. The Google link was sent to Libyan people via Twitter and WhatsApp groups. This study is part of a large project with researchers' participation from Anbar and Diyala Universities in Iraq, Bezmialem Vakif University in Turkey, the Misrata University in Libya. Briefly, the sampling technique and data collection process have been reported in detail previously $[12,13]$.

\section{Inclusion and exclusion criteria}

All Libyan people, 18 years of age or over, understand the questionnaire's content and willing to participate are included in the study. However, the study excluded the Libyan people from outside Libya, unwilling to participate, and those aged $<18$.

\section{Sample size}

According to the World Bank (WB) data for 2019, the total number of Libyan people estimated to be $6,777,452$ [29]. The sample size calculator arrived at 267 participants, using a margin of error of $\pm 6 \%$, a confidence level of $95 \%$, a $50 \%$ response distribution, and 6,777,452 people [30]. Non-response correction $=10 \%$. Thus, the total sample size was 294 .

\section{Study tool}

A semi-structured questionnaire was developed and tried by the authors earlier $[12,13]$. Considering adherence to the Centers for Disease Control and Prevention (CDC) guidelines [31], The questionnaire was written in the English language, and then it was translated into the Arabic language. Twenty respondents (not included in the study) were recruited to test pilot the study tool. Content validation was performed with a content validity rate [32,33]. "The first page of the online questionnaire contained an assurance of the freedom to participate or withdraw and that all information and opinions submitted would be anonymous and confidential". The questionnaire contains four main sections. The first section contained information about the participants' social and demographic characteristics, including age, gender, marital status, education, employment, place of residency, income level, and self-rated health status. The second section of the questionnaire was designed to assess participants' knowledge of COVID-19. This section contained 20 items focusing on the transmission of the Coronavirus, the clinical symptoms that appear on the infected person, the treatment protocol, and the groups most vulnerable to infection, in addition to information on isolation and prevention strategies control of the epidemic. In the third section of the questionnaire, there were 11 items to evaluate participants 'attitudes towards COVID-19, using a five-point Likert scale to determine the level of participants' agreement ranging from "1" 'Strongly disagree' to "5" 'Strongly agree'. The fourth section of the questionnaire has six questions recruited to evaluate respondents' practices and behaviors toward COVID19.

\section{Independent variables}

For sociodemographic variables, gender was coded as one for females and zero for males. The age variable was reported in six groups: "18-24", "25-34", "35-44", "45-54", "55-64", and ">64" years old. Moreover, the age was categorized into two categorize codded zero for less than 45 years and coded one for 45 years and above. Marital status was captured as binary, and a value of one was used for married and zero for otherwise. Education was categorized and coded into zero (high academic) for college/university degree, postgraduate degree, and one (low educated) for high school or below. Work status categorized and the value of zero given to employed and value of one given to unemployed. Place of residency coded as zero for rural and one for urban. Monthly income (Libyan Dinar, LYD 1 = USD 0.221 ) was divided into four categories: <USD 200, USD 200 
to $<400$, USD 400 to1000, and more than USD1000. The selfrated health status was reported in a scale ranging from "very bad" to "very good," a scale ranged from "1" to "5". Moreover, the self-rated health status was categorized into poor health (very bad, bad, moderate) and good health (good and very good).

\section{Dependent variables}

Three options (true or false, with an additional option 'I do not know) were made for the participants to express their opinion on the elements of knowledge. The correct answer was awarded one score, while the incorrect or uncertain answers (I do not know) were given a score of zero. The overall knowledge score ranged from zero to 20, with higher scores indicating better knowledge of COVID-19. Items were evaluated for internal reliability using Cronbach's alpha. Cronbach's alpha coefficient was 0.75 , indicating internal reliability.

Likert scale was recruited to calculate the respondents' answers on the questions related to attitude toward COVID-19: "1=strongly disagree, $2=$ disagree, $3=$ undecided, $4=$ agree, and $5=$ strongly agree". Scores were calculated by averaging respondents' answers to the eleven statements. Total scores ranged from eleven to 55, with high scores indicating positive attitudes. The Likert scales were assessed for internal reliability, using Cronbach's alpha. Cronbach's alpha coefficient was 0.81, indicating internal reliability. The options "yes" or "no" allowed respondents to rank their practice toward COVID-19 infection. Each answer that reflected good practice was given one score, and a score of zero was given for answers that reflected bad practice. The total score ranged from zero to six, with high scores indicating better practices.

\section{Statistical analysis}

Univariate analysis was recruited to tabulate the frequency of social and demographic statistics. An independent sample t-test and one-way analysis of variance (ANOVA) were used to assess differences in mean values for KAP scores. The overall mean differences were estimated using a Bartlett test [34]. A multivariable linear regression analysis was performed to identify factors related to knowledge, attitudes, and practice. All analyses were conducted using SPSS version 16 .

\section{Results}

\section{Demographic information}

A total of 294 participants completed the questionnaire. After excluding seven respondents who reported age less than 18 , the final sample consisted of 287 participants. As shown in table 1; of the total sample, 154 (53.7\%) were men. Most of the sample, 203 respondents $(70.7 \%$ ), were in the age group less than 45 years old. Of the participants, 176 were married (61.3\%), and $111(38.7 \%)$ were unmarried (single, widow, divorce). More than half of the sample, 154 (53.7\%), had a low education level compared to $133(45.3 \%)$ who had a college or university degree. Respondents were grouped according to monthly income, with $116(40.4 \%)$ in the USD 200-399 group, 87 $(30.3 \%)$ in the USD $400-1000$ group and $45(15.7 \%)$ in the $<$ USD200 group, and $39(13.6 \%)$ in the >USD1000 group. In terms of work status, 128 (44.6\%) were employed, $159(55.4 \%)$ were unemployed. Most of the respondents were urban residents $(229,79.8 \%)$. Most of the respondents perceived their health good $(116,40.4 \%)$ and very good $(88,30.7 \%)$, respectively.

KAP scores by social and demographic characteristics As shown in Table 2, the mean COVID-19 knowledge score was 16.20 ( $\mathrm{SD}=2.28$, range: $9-20)$, and the overall accuracy rate for the knowledge test was $81.00 \%(16.20 / 20 * 100)$. The mean attitude score for COVID-19 was 39.09 ( $\mathrm{SD}=3.68$, range: $11-55)$, indicating $(71.1 \%)$ positive attitudes. The mean score for practices for COVID-19 was 5.02 ( $\mathrm{SD}=1.20$, range: $0-6)$, indicating (83.7\%) acceptable practices. Table 3 presents the mean of KAP scores towards COVID-19 by different social and demographic characteristics in Libya. Knowledge scores significantly differed across gender, marital status, residence places, education level, income status, and health status. Gender and employment are shown as influential factors in Attitude scores. Gender, marital status, and health status are the influential factors in Practice scores $(P<0.05)$. Regression analysis showed that female gender $(P=0.037)$, marital status of being married $(P=0.056)$, with a monthly income of USD 200 and more $(P=0.001)$ and living in an urban area $(P=0.000)$ were significantly associated with upper knowledge score. Female gender $(P=0.040)$ was the only variable that significantly associated with a positive attitude. Regarding practice score, married $(P=0.001)$ and female $(P=0.059)$ people had better practice, but poor-rated health statues significantly associated with weak practice $(P=0.018)$ (Table $4)$.

Table 1 Social and demographic characteristics of the study participants $(\mathrm{n}=287)$

\begin{tabular}{|c|c|c|}
\hline Variables & Category & Number (\%) \\
\hline \multirow[t]{2}{*}{ Gender } & Female & $133(46.3)$ \\
\hline & Male & $154(53.7)$ \\
\hline \multirow[t]{2}{*}{ Age group } & 45 years and more & $84(29.3)$ \\
\hline & $<45$ years & $203(70.7)$ \\
\hline \multirow[t]{2}{*}{ Marital status } & Married & $176(61.3)$ \\
\hline & Single & $111(38.7)$ \\
\hline \multirow[t]{2}{*}{ Education } & Low education & $154(53.7)$ \\
\hline & High education & $133(46.3)$ \\
\hline \multirow[t]{2}{*}{ Area Residence } & Urban & $229(79.8)$ \\
\hline & Rural & $58(20.2)$ \\
\hline \multirow[t]{2}{*}{ Employment status } & Unemployed & $159(55.4)$ \\
\hline & Employed & $128(44.6)$ \\
\hline \multirow[t]{4}{*}{ Level of income } & $<$ USD 200 & 45 (15.7) \\
\hline & USD200-399 & $116(40.4)$ \\
\hline & USD400-1000 & $87(30.3)$ \\
\hline & >USD1000 & 39 (13.6) \\
\hline \multirow[t]{5}{*}{ Self-rated health status } & Very bad & $7(2.4)$ \\
\hline & $\mathrm{Bad}$ & $29(10.1)$ \\
\hline & Moderate & $47(16.4)$ \\
\hline & Good & $116(40.4)$ \\
\hline & Very good & $88(30.7)$ \\
\hline
\end{tabular}

In table 5, similar findings to those reported in earlier studies among Iraqi people and the Syrian people resident in Turkey [12,13] where most $(90.0 \%)$ of the respondents had accurate knowledge related to "washing hands, wearing medical masks, avoiding touching their eyes, nose, and mouth with the 
unwashed hand", "clinical symptoms and its importance", "spread through cough and sneeze by infected people", "elderly people, people with chronic diseases in higher risk" and "the importance of healthy food and drinking water and isolation". About seventy percent of them have sufficient knowledge about antibiotics' effectiveness; however, forty percent do not have accurate knowledge about children affected by COVID-19 compared to Iraqi and Syrian people $[12,13]$.

In table 6, respondents agreed more than ninety percent to "maintaining a reasonable distance" and "washing hands" to protect individuals and society from coronavirus. More than eighty $(81.9 \%)$ percent reported that they believe in staying at home as an effective preventive measure. Half of the respondents thought that coronavirus would be successfully controlled, and $44.3 \%$ agreed that it was not late when the lockdown was implicated at the beginning of the epidemic.
More than seventy percent of them thought the Libyan government's strict measures were enough to win the battle against coronavirus. Most of the participants (81.5\%) thought that complying with the National Centre for Disease Control instructions will prevent coronavirus spread. About 80.3\% thought that the announced number related to infected and dead persons due to coronavirus are actual (Table 6).

In Table 7, more than eighty percent of participants did not attend a social event involving many people; however, $31.4 \%$ were in a crowded place. Most of the surveyed people (82.6\%) still engage in some social behavior such as shaking hands or kissing people. However, about ninety percent think seriously about social distancing, but still, seven percent not interested in washing hands after going to a public place or after blowing their nose, coughing, or sneezing, and $13.2 \%$ were not interested in washing things from outside the home.

Table 2 Number of questions, range, scores, and levels of knowledge, attitude, and practice $(n=287)$

\begin{tabular}{lllll}
\hline Variables & Number of questions & Range of score & Total scores (mean \pm SD) & Accuracy rate $(\%)$ \\
\hline Knowledge & 20 & $9-20$ & $16.20 \pm 2.28$ & 81.0 \\
Attitude & 11 & $11-55$ & $39.09 \pm 3.68$ & 71.1 \\
Practice & 6 & $0-6$ & $5.02 \pm 1.20$ & 83.7 \\
\hline
\end{tabular}

Table 3 Comparison of social and demographic characteristics and mean KAP score $(n=287)$

\begin{tabular}{|c|c|c|c|c|c|c|c|c|c|c|c|c|}
\hline \multirow[t]{2}{*}{ Variables } & & \multicolumn{2}{|c|}{ Total } & \multicolumn{3}{|c|}{ Knowledge } & \multicolumn{3}{|c|}{ Attitude } & \multicolumn{3}{|c|}{ Practice } \\
\hline & & $\mathrm{n}$ & $\%$ & Mean & SD & $P$ & Mean & $\mathrm{SD}$ & $P$ & Mean & $\mathrm{SD}$ & $P$ \\
\hline \multirow[t]{2}{*}{ Gender } & Female & 133 & 46.3 & 16.7 & 2.1 & 0.001 & 39.6 & 3.7 & 0.040 & 5.2 & 1.2 & 0.081 \\
\hline & Male & 154 & 53.7 & 15.8 & 2.4 & & 38.7 & 3.6 & & 4.9 & 1.2 & \\
\hline \multirow[t]{2}{*}{ Age group } & $\geq 45$ years & 84 & 29.3 & 16.3 & 2.4 & 0.586 & 39.4 & 4.5 & 0.336 & 5.1 & 1.2 & 0.358 \\
\hline & $<45$ years & 203 & 70.7 & 16.1 & 2.2 & & 39.0 & 3.3 & & 5.0 & 1.2 & \\
\hline \multirow[t]{2}{*}{ Marital status } & Married & 176 & 61.3 & 16.5 & 2.1 & 0.002 & 38.9 & 3.3 & 0.189 & 5.2 & 1.1 & 0.001 \\
\hline & Single & 111 & 38.7 & 15.7 & 2.5 & & 39.5 & 4.2 & & 4.7 & 1.3 & \\
\hline \multirow[t]{2}{*}{ Education level } & Low education & 154 & 53.7 & 15.8 & 2.5 & 0.005 & 39.3 & 3.4 & 0.275 & 5.1 & 1.2 & 0.535 \\
\hline & High education & 133 & 46.3 & 16.6 & 1.9 & & 38.8 & 3.3 & & 5.0 & 1.3 & \\
\hline \multirow[t]{2}{*}{ Residency } & Urban & 229 & 79.8 & 16.7 & 1.8 & 0.000 & 39.2 & 3.7 & 0.199 & 5.1 & 1.1 & 0.271 \\
\hline & Rural & 58 & 20.2 & 14.0 & 2.8 & & 38.5 & 3.7 & & 4.9 & 1.4 & \\
\hline \multirow[t]{2}{*}{ Employment } & Unemployed & 159 & 55.4 & 16.0 & 2.1 & 0.160 & 38.7 & 3.8 & 0.030 & 5.0 & 1.2 & 0.710 \\
\hline & Employed & 128 & 44.6 & 16.4 & 2.4 & & 39.6 & 3.4 & & 5.0 & 1.2 & \\
\hline \multirow[t]{4}{*}{ Level of income } & $<$ the USD200 & 45 & 15.7 & 15.2 & 2.6 & 0.001 & 38.0 & 3.9 & 0.103 & 4.9 & 1.4 & 0.389 \\
\hline & USD200-399 & 116 & 40.4 & 16.1 & 2.3 & & 39.4 & 4.0 & & 5.1 & 1.1 & \\
\hline & USD400-1000 & 87 & 30.3 & 16.3 & 2.1 & & 39.4 & 3.1 & & 4.8 & 1.3 & \\
\hline & >USD1000 & 39 & 13.6 & 17.3 & 1.6 & & 38.6 & 3.3 & & 5.2 & 0.9 & \\
\hline \multirow[t]{5}{*}{ Self-rated health status } & Very bad & 7 & 2.4 & 18.6 & 0.5 & 0.009 & 38.5 & 4.1 & 0.584 & 5.0 & 1.0 & 0.081 \\
\hline & $\mathrm{Bad}$ & 29 & 10.1 & 15.7 & 2.4 & & 38.6 & 4.3 & & 5.5 & 0.8 & \\
\hline & Moderate & 47 & 16.4 & 15.7 & 2.9 & & 39.7 & 4.3 & & 5.2 & 0.9 & \\
\hline & Good & 116 & 40.4 & 16.1 & 1.9 & & 39.2 & 3.3 & & 4.9 & 1.2 & \\
\hline & Very good & 88 & 30.7 & 15.6 & 2.2 & & 39.1 & 3.4 & & 4.9 & 1.4 & \\
\hline
\end{tabular}

\section{Discussion}

To our knowledge, this study is the first national study to explore the knowledge, attitude, and practice of the Libyans towards the Novel Coronavirus in 2020. Likewise to our earlier two studies conducted among the Iraqi and Syrian people resident in Turkey [12,13], the Libyans scored $81.0 \%$ correct rate of knowledge about the COVID-19 pandemic. The findings of this study are similar to previous study conducted in neighboring Arabic and north African country such as Sudan (78.2\%) [14], and higher than rates reported in Egypt (70.2\%) [15] and some other African countries such as Northern Nigeria (65.4\%) [16], however, Libyans rated knowledge lower than other countries such as China (90.0\%) [17], Cameroon (84.19\%) [18], Saudi Arabi (81.6\%) [19], Malaysia (80.5\%) [20]. 
Table 4 Regression results of KAP-related factors for COVID-19 $(n=287)$

\begin{tabular}{|c|c|c|c|c|c|c|c|c|}
\hline \multirow[t]{2}{*}{ Variable } & \multirow[t]{2}{*}{$\mathrm{B}$} & \multirow[t]{2}{*}{ SE } & \multirow[t]{2}{*}{ Beta } & \multirow[t]{2}{*}{$\mathrm{t}$} & \multirow[t]{2}{*}{$P$-value } & $95 \% \mathrm{CI}$ & \multirow[t]{2}{*}{ Tolerance } & \multirow[t]{2}{*}{ VIF } \\
\hline & & & & & & lower-Upper & & \\
\hline \multicolumn{9}{|c|}{ Knowledge (Durbin-Watson= 1.827) } \\
\hline USD 200 and more & 0.435 & 0.129 & 0.170 & 3.304 & 0.001 & $(0.172,0.678)$ & 0.970 & 1.031 \\
\hline \multicolumn{9}{|l|}{ (vs <USD 200 years) } \\
\hline Married (VS single) & 0.447 & 0.242 & 0.095 & 1.851 & 0.056 & $(0.028,0.923)$ & 0.959 & 1.042 \\
\hline Female (VS Male) & 0.429 & 0.238 & 0.094 & 1.801 & 0.037 & $(0.040,0.898)$ & 0.942 & 1.061 \\
\hline Urban (VS Rural) & 2.388 & 0.300 & 0.421 & 7.957 & 0.000 & $(1.798,2.978)$ & 0.917 & 1.091 \\
\hline \multicolumn{9}{|c|}{ Attitude (Durbin-Watson= 1.734) } \\
\hline Female(VS Male) & 0.896 & 0.434 & 0.122 & 2.067 & 0.040 & $(0.043,1.750)$ & 0.995 & 1.000 \\
\hline \multicolumn{9}{|c|}{ Practice $($ Durbin-Watson $=1.689)$} \\
\hline Married (VS single) & 0.465 & 0.142 & 0.189 & 3.266 & 0.001 & $(0.185,0.745)$ & 0.987 & 1.013 \\
\hline Female (VS Male) & 0.234 & 0.140 & 0.097 & 1.676 & 0.059 & $(0.041,0.510)$ & 0.977 & 1.024 \\
\hline Poor-rated health & -0.361 & 0.152 & -0.137 & -2.371 & 0.018 & $(-0.661,0.061)$ & 0.989 & 1.012 \\
\hline (vs. Good -rated health) & & & & & & & & \\
\hline
\end{tabular}

Like other studies conducted in China [21], India [22], and Bangladesh [23], the higher rates of knowledge correlated with a higher level of education among the respondents. Young people and especially the female gender, are often the group that uses more social media, which increases their motivation to get more news and information about the COVID-19 pandemic than the males and older people. Moreover, the linear regression analysis showed that knowledge was affected by a high percentage of respondents in urban areas. Similar findings were seen in India [22], Ethiopia [24], Syrian residents in Turkey and Iraq [12,13]. More than $90 \%$ of Libyans resident in urban centers and cities, where universities and educational centers abound, and therefore knowledge rates about COVID-19 increase among highly educated and urban residents. The lowest average for Libyan salaries is 580 LYD (Equivalent to USD 128.5).

In this study, Libyan people who have a monthly income of USD 200 or more are significantly associated with good knowledge. Studies from Malaysia [20], Bangladesh [23], Iraq [12] found that good knowledge about COVID-19 significantly related to having a job with a fixed salary. The global economic situation is witnessing a steady deterioration as the Corona pandemic continues. The adverse effects of the pandemic went beyond the health status to include the psychological, social, and economic condition of the population in general [35]. Countries that suffer from an unstable political and economic situation, whose citizens are subject to restrictions on access to information. Most Libyans agreed that leaving a social distance (96.9\%), washing hands (97.6\%), and staying at home (80.9\%) are the best ways to control the pandemic. Similar findings recorded in China [21], Bangladesh [23], Iraq [12].

Inline to previous studies [19, 22, 25], the Libyans expressed an optimistic attitude towards the COVID-19 pandemic: more than half $(50.6 \%)$ of them believed that the pandemic would be successfully controlled, and more than seventy percent have confidence in the Libyan government's measures to win the battle against the virus. Furthermore, $81.5 \%$ of the participants stressed the importance of adhering to the National Center for Disease Control instructions to prevent the spread of the
Coronavirus. Most of the participants in this study agreed that the complete lockdown was an effective measure to prevent the spread of the Coronavirus, but it harmed the family's economic situation. Libyan women showed more commitment to protection standards from the Coronavirus, with more responsibility than men. Similar to earlier studies in Iraq [12] and Spain [36] finding of this study showed that females were significantly $(P=0.040)$ associated with a positive attitude to COVID-19 than the males. Libyans responded positively to the social situation resulting from the epidemic, and most of them $(82.6 \%)$ did not engage in any social events and social behavior, such as shaking hands or kissing. Moreover, public awareness improved, leading to more interest in practicing social distancing and washing hands or things brought from outside the home. The media may have a positive role in raising awareness among citizens, and the accumulation of information among the population due to the length of the pandemic and the data collected one year after the invasion of disease. Findings of the regression analysis showed that married $(P=0.001)$ and female gender sex $(P=0.059)$ were significantly more likely to practice protective measures against the spread of the coronavirus than their counterparts. However, those who ranked their health as poor $(P=0.018)$ were less likely to practice protective measures against the spread of the coronavirus than their counterparts.

Likewise, Brooks DJ and Saad L [37] account for the higher mortality rate among males than females due to the indifference of men. A previous study conducted by Galasso et al. [38] found that most women believe that coronavirus is a serious health problem. Therefore it is necessary to closely identify the pandemic, listen to instructions, adhere to safety procedures, and comply with policies. Unlike some earlier studies [12, 19], the results of this study found no significant difference among the Libyans in various age groups in terms of commitment to health prevention measures. However, some published reports from the World Health Organization [39] suggested that young people are less likely to be infected with the Coronavirus than the older age group. 


\section{Conclusion}

In conclusion, Libyan citizens showed a good level of knowledge, attitudes, and practices towards COVID-19 compared to some neighboring countries at the Arabic and African levels. The most prominent determinants of KAP towards COVID-19 were social, demographic, and economic variables such as gender, marital status, residence, income, and self-perceived health status. As the battle against the Corona pandemic continues, researchers expect that the results of this study and similar studies will enhance the Libyan government's ability and the National Center for Disease Control to adopt effective policies to control the spread of COVID-19 among citizens and immigrants of other nationalities.

Table 5 Correct responses to knowledge statements regarding COVID-19 ( $\mathrm{n}=313)$

\begin{tabular}{|c|c|c|}
\hline No. & Statement & $\mathbf{N}(\%)$ \\
\hline 1 & Corona is a viral disease that spreads from person to person at a distance of up to two meters ( 6 feet) & $220(76.7)$ \\
\hline 2 & Corona spreads through respiratory droplets that occur when infected people cough and sneeze. & 284(99.0) \\
\hline 3 & $\begin{array}{l}\text { Corona infection may occur by touching or kissing the contaminated surfaces or objects and then touching the mouth, nose, } \\
\text { or possibly the eyes. }\end{array}$ & 262(91.3) \\
\hline 4 & Eating or touching wild animals can lead to infection with the Coronavirus. & $144(50.2)$ \\
\hline 5 & People infected with COVID-19 cannot transmit the virus to others when a fever is not present. & 204(71.1) \\
\hline 6 & The main clinical symptoms of COVID-19 are fever, fatigue, dry cough, myalgia, and shortness of breath. & 276(96.2) \\
\hline 7 & Unlike the common cold, congestion, runny nose, and sneezing are less common in people infected with COVID-19. & 189(65.9) \\
\hline 8 & Antibiotics are effective in treating COVID-19. & 202(70.4) \\
\hline 9 & $\begin{array}{l}\text { Currently, there is no effective cure for COVID-19, but early symptomatic and supportive treatment can help most patients } \\
\text { recover from the diseases. }\end{array}$ & 254(88.5) \\
\hline 10 & $\begin{array}{l}\text { The elderly and people who suffer from serious chronic diseases such as heart or lung disease and diabetes have a doubled } \\
\text { risk of developing serious complications from developing a COVID-19. }\end{array}$ & 281(97.9) \\
\hline 11 & Pregnant women are more susceptible to infections than non-pregnant women. & 201(70.0) \\
\hline 12 & Children are less likely to be infected with COVID- 19 than adults. & 177(61.7) \\
\hline 13 & Children or young people do not need to take protective measures against COVID-19 transmission. & 259(90.2) \\
\hline 14 & $\begin{array}{l}\text { people must wash their hands with soap and water or use a hand sanitizer containing at least } 60 \% \text { alcohol for at least } 20 \\
\text { seconds. After being in a public place, after nose-blowing, coughing, or sneezing, }\end{array}$ & $270(94.1)$ \\
\hline 15 & As a precaution, people should avoid touching their eyes, nose, and mouth with unwashed hands. & 272(94.8) \\
\hline 16 & Wearing medical masks is very important to prevent corona infection. & 269(93.7) \\
\hline 17 & People should only wear a mask if they are infected with the virus or care for someone with suspected COVID-19 infection. & 194(67.6) \\
\hline 18 & Healthy food and drinking water strengthen the body's immunity and resistance against COVID-19. & 271(94.4) \\
\hline 19 & Isolation and treatment of people infected with the COVID-19 are effective ways to reduce the virus's spread. & $282(98.3)$ \\
\hline 20 & $\begin{array}{l}\text { People being in contact with someone infected with COVID-19 should be immediately quarantined, in an appropriate } \\
\text { location, for a general observation period of } 14 \text { days. }\end{array}$ & 252(87.8) \\
\hline
\end{tabular}

$\underline{\text { Table } 6 \text { Responses to attitudinal statements regarding COVID-19 ( } \mathrm{n}=313)}$

\begin{tabular}{|c|c|c|c|c|c|c|}
\hline No. & Statements & $\begin{array}{l}\text { Strongly } \\
\text { agree }\end{array}$ & Agree & $\begin{array}{l}\text { Do not } \\
\text { know }\end{array}$ & Disagree & $\begin{array}{l}\text { Strongly } \\
\text { disagree }\end{array}$ \\
\hline 1 & $\begin{array}{l}\text { Maintaining a reasonable distance from others is very important to avoid } \\
\text { the spread of coronavirus. }\end{array}$ & 134(46.7) & $144(50.2)$ & $6(2.1)$ & $0(0)$ & $3(1.0)$ \\
\hline 2 & $\begin{array}{l}\text { Hand washing is necessary to protect individuals and society from the } \\
\text { coronavirus. }\end{array}$ & $148(51.6)$ & $132(46.0)$ & $4(1.4)$ & $0(0)$ & $3(1.0)$ \\
\hline 3 & $\begin{array}{l}\text { Staying at home is an effective preventive measure to protect individuals } \\
\text { and society from coronavirus exposure. }\end{array}$ & $76(26.5)$ & $159(54.4)$ & $15(5.2)$ & $33(11.5)$ & $4(1.4)$ \\
\hline 4 & I think the Corona epidemic can be successfully controlled. & $26(9.1)$ & $119(41.5)$ & $86(30.5)$ & $46(16.0)$ & $10(3.5)$ \\
\hline 5 & $\begin{array}{l}\text { The strict measures taken by the Libya government are sufficient to win } \\
\text { the battle against coronavirus. }\end{array}$ & $40(13.9)$ & $163(56.8)$ & $53(18.5)$ & $24(8.4)$ & $7(2.4)$ \\
\hline 6 & $\begin{array}{l}\text { Complying with the National Safety Committee of the Ministry of Health } \\
\text { instructions will prevent the spread of corona. }\end{array}$ & $67(23.3)$ & $167(58.2)$ & $40(13.9)$ & $12(4.2)$ & $1(0.3)$ \\
\hline 7 & $\begin{array}{l}\text { The complete lockdown was an effective measure to prevent the spread } \\
\text { of coronavirus, but it negatively affected the family's economic situation. }\end{array}$ & $112(39.0)$ & $146(50.9)$ & $10(3.5)$ & $18(6.3)$ & $1(0.3)$ \\
\hline 8 & $\begin{array}{l}\text { I think the figures that announced the number of infected people and the } \\
\text { number of deaths due to coronavirus are exaggerated. }\end{array}$ & $15(5.2)$ & $41(14.3)$ & $105(36.6)$ & $89(31.0)$ & $37(12.9)$ \\
\hline 9 & $\begin{array}{l}\text { I still think that Corona Virus is a hoax, and there is no need to take } \\
\text { precautions. }\end{array}$ & $3(1.0)$ & $3(1.0)$ & $30(10.5)$ & $111(38.7)$ & $140(48.8)$ \\
\hline 10 & I have a growing concern about the second peak of coronavirus cases & $28(9.8)$ & $129(44.9)$ & $81(28.2)$ & $43(15.0)$ & $6(2.1)$ \\
\hline 11 & $\begin{array}{l}\text { When the lockdown introduced at the beginning of the epidemic, I felt it } \\
\text { was implemented too late }\end{array}$ & $30(10.5)$ & $97(33.8)$ & $57(19.9)$ & $96(33.4)$ & $7(2.4)$ \\
\hline
\end{tabular}


Table 7 Responses to practice statements regarding COVID-19 (n=313)

\begin{tabular}{|c|c|c|c|}
\hline No. & Statement & Yes $(\%)$ & No $(\%)$ \\
\hline 1 & $\begin{array}{l}\text { Have you recently attended a social event (such as a wedding party, funeral parlor, etc.) involving } \\
\text { many people? }\end{array}$ & $50(17.4)$ & $237(82.6)$ \\
\hline 2 & Have you recently been in a crowded place? & $90(31.4)$ & 197(68.6) \\
\hline 3 & $\begin{array}{l}\text { Have you recently avoided shaking hands or kissing or any social behavior that calls for meeting } \\
\text { and closeness? }\end{array}$ & $50(17.4)$ & $237(82.6)$ \\
\hline 4 & $\begin{array}{l}\text { Have you seriously thought about practicing social distancing and leaving a distance when talking } \\
\text { to people? }\end{array}$ & $254(88.5)$ & $33(11.5)$ \\
\hline 5 & $\begin{array}{l}\text { Recently, have you become more interested in washing your hands with soap and water frequently, } \\
\text { for at least } 20 \text { seconds, especially after going to a public place or after blowing your nose, coughing, } \\
\text { or sneezing? }\end{array}$ & $266(92.7)$ & $21(7.3)$ \\
\hline 6 & $\begin{array}{l}\text { Recently, have you become more interested in washing things that you bring from outside the home, } \\
\text { including fruits and vegetables? }\end{array}$ & $249(86.8)$ & $38(13.2)$ \\
\hline
\end{tabular}

\section{Abbreviation}

COVID-19: Coronavirus; SARS coronavirus or SARS-CoV: Severe Acute Respiratory Syndrome; CDC: Centers for Disease Control and Prevention; WB: World Bank; MoH: Ministry of Health; KAP: Knowledge, Attitude, Practice; LYD: Libyan Dinar; USD: United State Dollar; M: Mean; SD: Standard Deviation; ANOVA: One-Way Analysis of Variance

\section{Declaration}

Acknowledgment

We want to thank Mr. Anmar Shukur Mahmood for his outstanding efforts in helping to prepare the questionnaires and the necessary links and distribution through the social networking sites. We also extend our thanks to all respondents to the survey during the Coronavirus pandemic.

\section{Funding}

The authors received no financial support for their research, authorship, and/or publication of this article.

\section{Availability of data and materials}

Data will be available by emailing drsaadalezzi@gmail.com.

\section{Authors' contributions}

Saad Ahmed Ali Jadoo (SAAJ) is the principal investigator of this manuscript (Original manuscript) who designed the study and coordinated all aspects of the research, including the study design, analysis, and interpretation of data, drafting the work, writing the manuscript, and reviewed and approved the manuscript. SAAJ, OMD, MZ, MAA, PT, MAMA, and SMY contributed to the study concept, design, writing, reviewing, editing, and approving the manuscript in its final form. All authors have read and approved the final manuscript.

\section{Ethics approval and consent to participate}

We conducted the research following the Declaration of Helsinki, and the protocol was approved by the Ethics Committee of the Scientific Issues and Postgraduate Studies Unit (PSU), College of Medicine, University of Anbar (Ref: SR/368 at 19-July-2020); the Ethics Committee of the College of Medicine, Diyala University (Ref: 1250 at 15-July-2020); National Cancer Institute, Misrata, Libya (Ref: 0000 at 91August-2020). Moreover, web-based informed consent was obtained from each participant after explaining the study objectives and the guarantee of secrecy.
Consent for publication

Not applicable

\section{Competing interest}

The authors declare that they have no competing interests.

\section{Open Access}

This article is distributed under the terms of the Creative Commons Attribution 4.0 International License (http://creativecommons.org/licenses/by/4.0/), which permits unrestricted use, distribution, and reproduction in any medium, provided you give appropriate credit to the original author(s) and the source, provide a link to the Creative Commons license, and indicate if changes were made. The Creative Commons Public Domain Dedication waiver (http://creativecommons.org/publicdomain/zero/1.0/) applies to the data made available in this article, unless otherwise stated.

\section{Author Details}

${ }^{1}$ Department of Public Health, Faculty of Medicine, Bezmialem Vakif University, Istanbul, Turkey. ${ }^{2}$ Department of Surgery, Facility of Medicines Misurata University. National Cancer Institute, Misurata -Libya. ${ }^{3}$ Department of Surgery, Faculty of Medicine, Misurata University, Misurata Medical Center, Misurata, Libya. ${ }^{4}$ Pharmacology Department, Faculty of Medicine Misurata University, Misurata, Libya. ${ }^{5}$ Department of Public Health, Hamidiye International School of Medicine, University of Health Sciences, Istanbul. Turkey. ${ }^{6}$ Department of family and community medicine, Faculty of Medicine, Anbar University, Anbar, Iraq. ${ }^{7}$ Department of Anatomy, Molecular Genetics, Faculty of Medicine, University of Diyala, Diyala, Iraq.

\section{Article Info}

Received: 10 January 2021

Accepted: 31 March 2021

Published: 16 April 2021

\section{References}

1. The World Bank, Data, Libya. Available from: https://data.worldbank.org/country/libya [Accessed on 10 February 2021].

2. United Nations, Economic and Social Commission Western Africa. An introductory study on the status, challenges and prospects of the Libyan economy : part III 
of a baseline study for the Libya socioeconomic dialogue project. Available from: https://www.unescwa.org/sites/www.unescwa.org/files/pu blications/files/introductory-study-status-challengesprospects-governance-institutions-libya-english_1.pdf [Accessed on 10 February 2021].

3. USAID. Landlinks; Libya. Available from: https://www.land-links.org/country-profile/libya/ [Accessed on 10 February 2021].

4. Megerisi T. Geostrategic Dimensions of Libya's Civil War, Africa Centre for Strategic Studies. May 18, 2020. Available from: https://africacenter.org/publication/geostrategicdimensions-libya-civil-war/ [Accessed on 10 February 2021].

5. WHO, Health Cluster, Health Sector Libya Annual Report 2020; 31 December 2020. Available from: https://www.who.int/health-cluster/countries/libya/HealthSector-Libya-Annual-Report-2020.pdf?ua=1 [Accessed on 10 February 2021].

6. World Health Organization. Regional Office for the Eastern Mediterranean. (2010). Country cooperation strategy for WHO and Libya: 2010-2015. World Health Organization. Regional Office for the Eastern Mediterranean. Available from: https://apps.who.int/iris/handle/10665/113220 [Accessed on 10 February 2021].

7. Ali Jadoo SA. Was the world ready to face a crisis like COVID-19? Journal of Ideas in Health;3(1):123-4. https://doi.org/10.47108/jidhealth.Vol3.Iss1.45

8. Bredan A, Bakoush O. COVID-19 epidemic in Libya. Libyan Journal of Medicine 2021; 16:1, 1871798. https://doi.org/10.1080/19932820.2021.1871798

9. Worldometer, Coronavirus in Libya. Available from: https://www.worldometers.info/coronavirus/country/libya/ [Accessed on 10 April 2021].

10. Ali Jadoo SA. The second wave of COVID-19 is knocking at the doors: have we learned the lesson. Journal of Ideas in Health;3(Special1):183-4. https://doi.org/10.47108/jidhealth.Vol3.IssSpecial1.72

11. WHO Director-General's opening remarks at the media briefing on COVID-19 - 11 March 2020. 2020. Available from:https://www.who.int/director-

general/speeches/detail/who-director-general-s-openingremarks-at-the-media-briefing-on-covid-19---11-march2020 [Accessed on 10 April 2021].

12. Ali Jadoo SA, Alhusseiny A, Yaseen S, Al-Samarrai M, Al-Rawi R, Al-Delaimy A, Abed M, Hassooni H. Knowledge, attitude, and practice toward COVID-19 among Iraqi people: a web-based cross-sectional study. Journal of Ideas in Health 2020;3(Special2):258-65. https://doi.org/10.47108/jidhealth.Vol3.IssSpecial\%202.59

13. Ali Jadoo SA, Dastan I, Al-Samarrai M, Yaseen S, Abbasi A, Alkhdar H, Al Saad M, Danfour O. Knowledge, attitude, and practice towards COVID-19 among Syrian people resident in Turkey. Journal of Ideas in Health 2020;3(Special2):278-85. https://doi.org/10.47108/jidhealth.Vol3.IssSpecial2.61

14. Hezima A, Aljafari A, Aljafari A, Mohammad A, Adel I. Knowledge, attitudes, and practices of Sudanese residents towards COVID-19. East Mediterr Health J. 2020 Jun 24;26(6):646-651. https://doi.org/10.26719/emhj.20.076.

15. Kasemy ZA, Bahbah WA, Zewain SK, Haggag MG, Alkalash SH, Zahran E, Desouky DE. Knowledge, Attitude and Practice toward COVID-19 among Egyptians. J Epidemiol Glob Health. 2020 Dec;10(4):378-385. https://doi.org/10.2991/jegh.k.200909.001.

16. Habib MA, Dayyab FM, Iliyasu G, Habib AG. Knowledge, attitude and practice survey of COVID-19 pandemic in Northern Nigeria. PLoS One. 2021 Jan 14;16(1):e0245176. https://doi.org/10.1371/journal.pone.0245176

17. Zhong BL, Luo W, Li HM, Zhang QQ, Liu XG, Li WT, Li Y. Knowledge, attitudes, and practices towards COVID-19 among Chinese residents during the rapid rise period of the COVID-19 outbreak: a quick online cross-sectional survey. Int J Biol Sci. 2020 Mar 15;16(10):1745-1752. https://doi.org/10.7150/ijbs.45221

18. Ngwewondo A, Nkengazong L, Ambe LA, Ebogo JT, Mba FM, Goni HO, Nyunaï N, Ngonde MC, Oyono JE. Knowledge, attitudes, practices of/towards COVID 19 preventive measures and symptoms: A cross-sectional study during the exponential rise of the outbreak in Cameroon. PLoS Negl Trop Dis. 2020 Sep 4;14(9): e0008700. https://doi.org/10.1371/journal.pntd.0008700

19. Al-Hanawi MK, Angawi K, Alshareef N, Qattan AMN, Helmy HZ, Abudawood Y, Alqurashi M, Kattan WM, Kadasah NA, Chirwa GC, Alsharqi O. Knowledge, attitude and practice toward COVID-19 among the public in the kingdom of saudi arabia: a cross-sectional study. Front Public Health. 2020 May 27; 8:217. https://doi.org/10.3389/fpubh.2020.00217

20. Azlan AA, Hamzah MR, Sern TJ, Ayub SH, Mohamad E. Public knowledge, attitudes and practices towards COVID19: A cross-sectional study in Malaysia. PLoS One. 2020 May 21;15(5): $\quad$ e0233668. https://doi.org/10.1371/journal.pone.0233668

21. Yue S, Zhang J, Cao M, Chen B. Knowledge, attitudes and practices of COVID-19 among urban and rural residents in china: a cross-sectional study. J Community Health. 2020 Aug 5:1-6. https://doi.org/10.1007/s10900-020-00877-x

22. Pal R, Yadav U, Grover S, Saboo B, Verma A, Bhadada SK. Knowledge, attitudes and practices towards COVID19 among young adults with Type 1 diabetes mellitus amid the nationwide lockdown in India: A cross-sectional survey. Diabetes Res Clin Pract 2020; 166:108344. https://doi.org/10.1016/j.diabres.2020.108344

23. Ferdous MZ, Islam MS, Sikder MT, Mosaddek ASM, Zegarra-Valdivia JA, Gozal D.Knowledge, attitude, and practice regarding COVID-19 outbreak in Bangladesh: An online-based cross-sectional study. PLOS ONE2020; $15(10)$ :

e0239254. https://doi.org/10.1371/journal.pone.0239254

24. Akalu Y, Ayelign B, Molla MD. Knowledge, attitude and practice towards COVID-19 among chronic disease patients at Addis Zemen hospital, northwest Ethiopia. Infect Drug Resist. 2020; 13:1949-1960. https://doi.org/10.2147/IDR.S258736

25. Hussain A, Garima T, Singh B, Ram R, Tripti R. Knowledge, attitudes, and practices towards COVID-19 
among Nepalese Residents: A quick online cross-sectional survey. AJMS 2020;11(3):6-1 https://doi.org/10.3126/ajms.v11i3.28485

26. Hweissa NAB, Shawesh FA, Krema SO, Mansour AA. Knowledge, attitude and practice (KAP) for preventing the coronavirus (COVID19) pandemic among Libyan health care workers. Libyan J Med Sci 2020;4:109-14

27. Elshwekh H, Atia A, Mohammed A, Shebani A, Abdo M. Assessing Knowledge and Perception of Libyan Health Workers Towards the Novel Coronavirus Disease (COVID-19): A Cross-Sectional Study. International Journal of Medical and Biomedical Studies2020; 4(12). https://doi.org/10.32553/ijmbs.v4i12.1545

28. Elhadi M, Buzreg A, Bouhuwaish A, Khaled A, Alhadi A, Msherghi A, Alsoufi A, Alameen H, Biala M, Elgherwi A, Elkhafeefi F, Elmabrouk A, Abdulmalik A, Alhaddad S, Elgzairi M, Khaled A. Psychological Impact of the Civil War and COVID-19 on Libyan Medical Students: A Cross-Sectional Study. Front Psychol. 2020 Oct 26;11:570435. https://doi.org/10.3389/fpsyg.2020.570435.

29. The World Bank, Population, total - Libya. Available from: https://data.worldbank.org/indicator/SP.POP.TOTL?locati ons=LY [Accessed on 10 April 2021].

30. Raosoft, sample size calculator. Available from: http://www.raosoft.com/samplesize.html?nosurvey [Accessed on 06-October 2020]

31. CDC. Centers for Disease Control and Prevention: Coronavirus (COVID-19) 2020. Available online at: https://www.cdc.gov/coronavirus/2019-nCoV/index.html [Accessed on 11 November 2020].

32. Ali Jadoo SA, Aljunid SM, Seher Nur Sulku, Al-Dubai SAR, Wan Puteh SE, Ahmed Z, Abdul Manaf MR, Sulong SB, Nur AM. Health system reform from the people's point of view: development of reliable and valid questionnaire. Malaysian Journal of Public Health Medicine 2013;13(2):65-76. 26.

33. Ali Jadoo SA, Sulku SN, Aljunid SM, Dastan I. Validity and reliability analysis of knowledge of, attitude toward and practice of a case-mix questionnaire among Turkish healthcare providers. JHEOR. 2014;2(1):96-107.

34. O'brien RG. A general ANOVA method for robust tests of additive models for variances. J Am Statist Assoc.1979; 74:877-80. https://doi.org/10.1080/01621459.1979.10481047

35. Ali Jadoo SA. COVID -19 pandemic is a worldwide typical biopsychosocial crisis. Journal of Ideas in Health.2020;3(2):152-4. https://doi.org/10.47108/jidhealth.Vol3.Iss2.58

36. de la Vega R, Ruíz-Barquín R, Boros S, Szabo A. Could attitudes toward COVID-19 in Spain render men more vulnerable than women? Global Public Health. 2020 Sep;15(9):1278-1291.

https://doi.org/10.1080/17441692.2020.1791212

37. Deborah Jordan Brooks, Lydia Saad. Double Whammy: Why the underrepresentation of women among workplace and political decision-makers matters in pandemic times. Politics \& Gender, 2020; 1 https://doi.org/10.1017/S1743923X20000628
38. Galasso V, Pons V, Profeta P, Becher M, Brouard S, Foucault M. Gender differences in COVID-19 attitudes and behavior: Panel evidence from eight countries. Proceedings of the National Academy of Sciences 2020; $117 \quad$ (44): 27285-27291. https://doi.org/10.1073/pnas.2012520117

39. WHO (2020), Statement - Older people are at highest risk from COVID-19, but all must act to prevent community spread. Available from: http://www.euro.who.int/en/health-topics/healthemergencies/coronavirus-covid-19/statements/statementolder-people-are-at-highest-risk-from-covid-19,-but-allmust-act-to-prevent-community-spread 